\title{
Strategy for Sustainable Village Status Improvement in Kundur Village Kepulauan Meranti District
}

\author{
Dadang Mashur \\ Public Administration- FISIP, University of Riau (Email: dadang.mashur@lecturer.unri.ac.id) \\ Yuni Novita Putri \\ Public Administration- FISIP, University of Riau (Email: yuninovitaputri@yahoo.com) \\ Risky Arya Putri \\ Public Administration- FISIP, University of Riau (Email: risky.arya@lecturer.unri.ac.id)
}

\begin{abstract}
This research discusses about strategies to sustainable improve village status in the village of Kundur, Kepulauan Meranti Regency. The problems and phenomena in this study are the selection of Kundur village to be one of the priority development target villages, the lower the IKE value in 2018-2019, and the IDM calculation 2018-2019 The purpose of this research (1) to find out the social, economic and ecology conditions in the Kundur village, (2) to find out the strategies carried out to continuously improve the status of the Kundur village. The research method used is a mixed method. From the results of the study, the existing conditions of social security get a sccore of 0,878 economic resilience of 0,600 ecology resilience of 0,850 . From the results of these scores get the Kundur village IDM score of 0,776. And the strategy that should be carried out by the Kundur village to improve the status of thee village is anaggresive and growing strategy, by making utilizing human resources in maintaining natural resources for sustainable development, innovation in adding village owned business entity (BUMDes) units in accordance with existing conditions, and addition of plantation production types.
\end{abstract}

\section{Introduction}

The Villages have genuine autonomy rights based on customary law, can determine the structure of government, manage and manage households, and own assets. The implementation of village autonomy requires the support and development of a development management system that encourages wider community involvement. Village development is an effort to improve the quality of life and for the greatest possible welfare (Undang-Undang No. 6 of 2014). State recognition and respect for villages accompanied by a redistribution of 
resources and full development authority as mandated by Undang-Undang No. 6 of 2014, gives a clear sign that that is where the village must become the foundation for developing Indonesia. The ministry of villages, development of disadvantaged areas, and transmigration of the Republic of Indonesia welcomed the law as a starting point for the (re) birth of a new village as well as a momentum to throw away the old village paradigm. Development in villages is very important because the majority of Indonesian citizens live in rural areas.. Based on the Decree of the Director-General of development and empowerment of village communities Number 201/2019, the number of villages in Indonesia is 74,954 villages. The essence of village development is to improve the conditions and standard of living of the community.

Sustainable development is a development that can meet the needs of the current generation without sacrificing future generations to meet their needs (Conrad) (Manafi et al (2009: 65). Sustainable development defined as a development process that optimizes the benefits of natural and human resources, by harmonizing natural resources with humans in development (Salim, 2010: 193). According to Tjiptoherijanto in Mukhlis (2010, 196), to achieve a state that allows sustainable development in general, it contains three important aspects, namely: aspects of sustainable economic growth, aspects of sustainable social development and aspects of sustainable environmental quality management. According to Pezzy in Mukhlis (2010: 193), the aspect of sustainability in development has a static definition and a dynamic definition. Static sustainability is defined as the use of renewable natural resources at a constant rate of technology. Meanwhile, dynamic sustainability is defined as the use of non-renewable resources at a changing rate of technology.

The number of villages in Indonesia has many impacts on high poverty rates in rural areas, so it is important to develop rural areas to be more advanced by trying to explore the potentials of each village so that it can be developed and functioned and increase the village's original income. An assessment of the level of welfare and development in an area requires benchmarks. This increase can be indicated by structural changes in several fields such as education, health, economy, politics, and culture (Arifah, 2018). In Indonesia, to see how advanced and developed a village is can be seen from its status.

The status of this village can be known through the progress and independence of the village which is stipulated in the Regulation of the Minister of Villages for Disadvantaged 
Areas and Transmigration Number 2 of 2016 concerning the Developing Village Index. Based on the developing village index, the village status classification includes independent villages, developed villages, developing villages, underdeveloped villages, and very disadvantaged villages. The Village Development Index (IDM) places the initiative and strong community capacity as the main basis in the process of progress and village empowerment, which includes aspects of social, economic, and ecological resilience (Setyowati, 2019).

The Village independence can be realized with a village community empowerment strategy, the output of community empowerment activities is the expansion of assets and capabilities of community members (especially the poor) so that they can improve a better quality of life for all members of society through self-help activities with the aim of strength or empowerment. or the ability concerned can improve welfare or be able to live independently (Amalia and Syawie, 2015). Through developing villages, it is hoped that it can support efforts to achieve the development goals of villages and rural areas, namely to alleviate 5000 underdeveloped villages and to increase 2000 independent villages as stated in the 2015-2019 national mid-term development plan (IDM, 2016).

The Developing Village Index classifies villages into five statuses, namely: very underdeveloped villages, left behind, developing, advanced, and independent with a national average value for Developing Village Index 0.566. The village status classification is determined by the following :

1. Very underdeveloped villages $:<0,491$

2. Underdeveloped villages $\quad:>0,491$ dan $<0,599$

3. Developing villages $\quad:>0,599$ dan $<0,707$

4. Advanced villages $\quad:>0,707$ dan $<0,815$

5. Independent villages $\quad:>0,815$

Based on the national long-term development plan (RPJPN) for 2005-2025, it has a vision for an Indonesia that is independent, advanced, just, and prosperous. Efforts to realize the vision of the RPJPN, the government implemented it in stages through the five-year national medium-term development plan (RPJMN). The 2020-2024 RPJMN has a vision of realizing an independent, advanced, fair, and prosperous Indonesian society through accelerating development in various fields by emphasizing the development of a strong economic structure based on competitive advantages in various areas supported by quality, competitive human resources. Kundur village is one of the 15,000 development target priority targets in the 2015-2019 national mid-term development plan (RPJMN). Of the 96 villages in 
the Meranti Islands Regency, 36 villages are priority villages for development targets in the 2015-2019 national long-term development plan (RPJMN).

Table 1.

IDM of Kundur Village 2018-2019

\begin{tabular}{cccccc}
\hline Years & & IDM & & TOTAL & STATUS \\
& IKS & IKE & IKL & & \\
\hline 2018 & 0,77143 & 0,55000 & 0,73333 & 0,68492 & Developing \\
2019 & 0,8171 & 0,5000 & 0,7333 & 0,6835 & Developing
\end{tabular}

Source : Ministry of Villages for Disadvantaged Areas and Transmigration

Information :

IKS : Social Resilience Index

IKE : Economic Resilience Index

IKL : Ecology Resilience Index

In 2018 the Kundur village got value from the results of the Build Village Index Calculation (IDM) 0.68492 with the status of a developing village. In 2018 there was a weakness in the Economic Resilience Index assessment with a value of 0.55000. In 2019 the results of the calculation of the Kundur Village IDM were 0.6835 with the status of the developing village. And in 2019 there was also a weakness in the Economic Resilience Index value with a value of 0.5000 , even this value was lower than the previous year.

Table 2.

IDM Score of Kundur Village in 2019

\begin{tabular}{llcc}
\hline No. & \multicolumn{1}{c}{ Index } & $\begin{array}{c}\text { Number of indicators } \\
\text { counted }\end{array}$ & $\begin{array}{c}\text { Sum of all indicator/index } \\
\text { scores }\end{array}$ \\
\hline 1. & $\begin{array}{l}\text { Social } \\
\text { Resilience } \\
\text { Index }\end{array}$ & 35 & 143 \\
2. & $\begin{array}{l}\text { Economic } \\
\text { Resilience }\end{array}$ & 12 & 30 \\
& $\begin{array}{l}\text { Index } \\
\text { Ecology }\end{array}$ & 3 & $\left(\frac{30}{60}=0,5000\right)$ \\
Resilience & Index & $\left(\frac{11}{15}=0,7333\right)$
\end{tabular}

Source: IDM Kundur Villages 2019 
Based on the problems, observations, and observations made, this study aims to analyze:

a. Kundur village was chosen as one of the priority target villages for development by the Ministry of Villages for disadvantaged areas development and transmigration from 2015-2019

b. The condition of the economic resilience index in Kundur village is getting lower from 2018-2019.

c. The final number of village index calculations for building a kundur village from 2018-2019 is getting lower even though it is in the same village status.

\section{Methods}

The research focus is for the Strategy to Improve Village Status in a Sustainable Way in Kundur Village, Meranti Islands Regency. The research method uses a mixed-method or mixed-method between qualitative and quantitative research. In this study, a sequential mixed-methods strategy is used, especially a sequential explanatory strategy. The data collection technique was done using observation, interviews, documentation and questionnaires. The qualitative data analysis was done by using triangulation technique and for quantitative data using SWOT analysis.

\section{Result and Discussion}

In the discussion of this research will explain the results of research on the strategy to improve village status from developing to being independent in the village of Kundur, Kepulauan Meranti district.

\section{Existing Condition of Kundur Village}

To determine the existing conditions of the village of Kundur, the researchers used the indicator guidelines in the Build Village Index (IDM).

\section{Social Resilience}

The social resilience index (IKS) consists of 38 indicators which are divided into 4 (four) dimensions, namely the first, the health dimension which consists of 7 (seven) indicators. second, the education dimension which consists of 8 (eight) indicators. Third, the dimension of social capital which consists of 15 (fiveteen) indicators. The fourth is the settlement dimension which consists of 8 (eight) indicators. 
So, the scores for the Social Resilience Index are:

$$
\begin{gathered}
I_{\text {Social }}=\frac{\sum_{1}^{n} \text { Social score }}{n_{\text {Social } \times \text { highest indicator score }}} \\
\begin{array}{c}
\text { Dimension health }+ \text { Dimension education }+ \text { Dimension of social capital } \\
+ \text { Dimension settlement }
\end{array} \\
\qquad \frac{167}{190} \\
\text { number of indicator } \times \text { highest indicator score } \\
=0,878
\end{gathered}
$$

So, at this time, Kundur village had a very good social resilience index, with a score of 0.878 in the very good category. Namely the combination of the total values of the dimensions of health, education, social capital and settlement. From the social resilience index, the low dimension is in the health dimension, namely a total score of 29 from the calculation of 7 indicators.

\section{Economic Resilience}

The economic resilience index consists of 1 (one) dimension, namely the economic dimension. Where in this dimension consists of 12 indicators So, the total score for economic resilience is:

$$
\begin{gathered}
I_{\text {Economic }}=\frac{\sum_{1}^{n} \text { Score Economic }}{n_{\text {Economic } \times \text { highest indicator score }}} \\
\square \quad \frac{36}{12 \times 5}=0,600
\end{gathered}
$$

\section{Ecology Resilience}

The ecology resilience index consists of 1 (one) dimension, namely the ecology dimension. Where in this dimension consists of 4 indicators. So, the total scores for Ecology resilience are:

$$
\begin{gathered}
I_{\text {Ecology }}=\frac{\sum_{1}^{n} \text { Score ecology }}{n_{\text {ecology } \times \text { highest indicator score }}} \\
\square \frac{17}{4 \times 5}=0,850
\end{gathered}
$$


So, at this time, Kundur village had an ecology resilience index with a score of 0.850 which was categorized as very good.So the building village index score (IDM) for the kundur village is as follows:

$$
\begin{aligned}
\mathrm{IDM} & =\frac{1}{3}(\mathrm{IKS}+\mathrm{IKE}+\mathrm{IKL}) \\
& =\frac{1}{3}(0,878+0,600+0,850) \\
& =\frac{1}{3}(2,328) \\
& =0,776
\end{aligned}
$$

From the IDM score, the Kundur village was 0.776 included in the developed village category. With the score that is in the indicator of social and ecology resilience index which is very good, but there are weaknesses in the assessment of the indicator score in the index of economic resilience.

\section{Strategy to increase village status}

\section{SWOT Analysis}

To determine where the position of Kundur village is and what strategies the government and community of Kundur village should do in order to improve the village

\begin{tabular}{|c|c|c|c|c|}
\hline \multicolumn{5}{|c|}{ Strength (Strenghts) } \\
\hline No & Factor & Weight & Rating & Weight $\times$ Rating \\
\hline 1 & $\begin{array}{l}\text { Village autonomy and } \\
\text { ADD }\end{array}$ & 0,20 & 3 & 0,60 \\
\hline 2 & $\begin{array}{l}\text { Have Village Original } \\
\text { Income }\end{array}$ & 0,20 & 2 & 0,40 \\
\hline 3 & $\begin{array}{l}\text { Increase in the number } \\
\text { of production }\end{array}$ & 0,30 & 4 & 1,20 \\
\hline 4 & Has a large forest & 0,20 & 2 & 0,40 \\
\hline 5 & Availability of food stalls & 0,10 & 2 & 0,20 \\
\hline & Total & 1,00 & 13 & 2,80 \\
\hline \multicolumn{5}{|c|}{ Weakness (Weakness) } \\
\hline No & Factor & Weight & Rating & Weight $\times$ Rating \\
\hline
\end{tabular}
status in a sustainable manner using a SWOT analysis diagram

Tabel 3.

SWOT diagram calculation 


\begin{tabular}{|c|c|c|c|c|}
\hline 1 & $\begin{array}{l}\text { Inadequate } \\
\text { infrastructure }\end{array}$ & 0,60 & 1 & 0,60 \\
\hline 2 & Has large peatlands & 0,40 & 2 & 0,40 \\
\hline & Total & 1,00 & 3 & 1,00 \\
\hline \multicolumn{5}{|c|}{ Opportunities (Opportunities) } \\
\hline No & Factor & Weight & Rating & Weight $\times$ Rating \\
\hline 1 & $\begin{array}{l}\text { Development priority } \\
\text { target villages }\end{array}$ & 0,30 & 2 & 0,60 \\
\hline 2 & $\begin{array}{l}\text { There is assistance from } \\
\text { the Ministry of Village, } \\
\text { PDTT, clean water } \\
\text { management machines }\end{array}$ & 0,70 & 3 & 2,10 \\
\hline & Total & 1,00 & 10 & 2,70 \\
\hline \multicolumn{5}{|c|}{ Threat (Threats) } \\
\hline No & Factor & Weight & Rating & Weight $\times$ Rating \\
\hline 1 & $\begin{array}{l}\text { Forest fire natural } \\
\text { disasters that come at } \\
\text { any time }\end{array}$ & 0,40 & 1 & 0,40 \\
\hline 2 & $\begin{array}{l}\text { Information } \\
\text { development }\end{array}$ & 0,30 & 2 & 0,60 \\
\hline 3 & $\begin{array}{l}\text { Some of the IKE } \\
\text { indicators that are } \\
\text { impossible are met }\end{array}$ & 0,30 & 1 & 0,30 \\
\hline & Total & 1,00 & 3 & 1,30 \\
\hline
\end{tabular}

Information on weight: The greater the value on the weight, the higher the importance of the indicator. 
Tabel 4.

Rating Description

\begin{tabular}{lcl}
\hline $\begin{array}{l}\text { Positive (Strengths } \\
\text { and Opportunities) }\end{array}$ & Score & \multicolumn{1}{c}{ Status } \\
\hline \multicolumn{1}{c}{ Status } & $\begin{array}{l}\text { Negative } \\
\text { Theaknesses }\end{array}$ \\
\hline No effect & 1 & Very influential \\
Quite Influential & 2 & Take effect \\
Take effect & 3 & Quite Influential \\
Very influential & 4 & No effect \\
\hline
\end{tabular}

Determine the point $(x, y)$

$$
\begin{gathered}
(\mathrm{x}, \mathrm{y}) \\
\frac{S-W}{2}, \frac{o-T}{2} \\
\frac{2,80-1,00}{2}, \frac{2,70-1,30}{2} \\
\frac{1,80}{2}, \frac{1,40}{2} \\
(0,90),(0,70)
\end{gathered}
$$

Figure 1.

Determination of the points $x$ and $y$

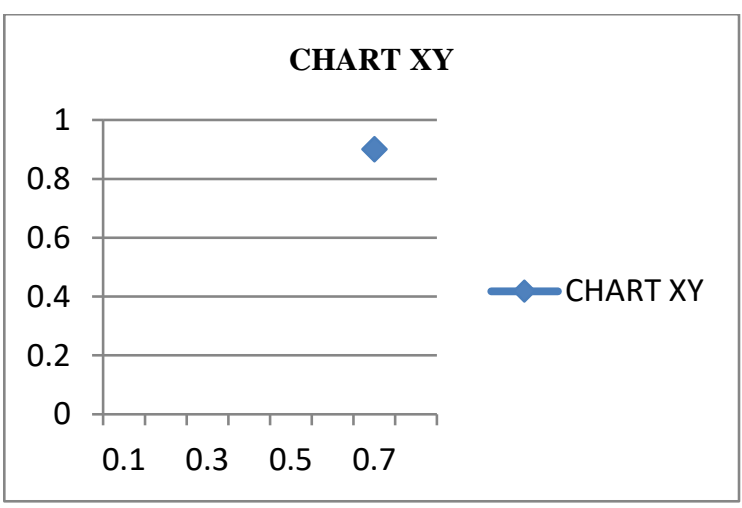

Figure 1 explains that the right strategy to improve the status of Kundur in a sustainable manner is a strategy that is in quadrant (I), which is aggressive or growing, in 
which the community and government are in prime and good condition. Where in the strategy in quadrant (I) there is an SO strategy which consists of:

1. Utilizing human resources in safeguarding natural resources for sustainable development, namely making natural resources (forests) the main source of livelihood for the community but by preserving the natural ecology. And there is a mutualism relationship between humans and nature. Where nature is able to have an impact on the economy of the community, and the community is able to preserve nature and protect nature from disasters such as forest fires.

2. Innovation in adding units in Village-Owned Enterprises (BUMDes) that are adjusted to the development of the situation. Namely adjusting the addition of business units within the BUMDesa according to the needs of the community and the direction of the community's economy.

3. Additional types of plantation production, where at this time the community only produces types of production such as rubber, as well as ginger and some coconuts. And to increase the type of plantation production, the villagers can plant palawija, jelutung (gum for gum), geronggong (the trees can be used to become wood for bridges), where these plants can be planted in peat-textured soil.

From the results of the SWOT analysis, the researcher made a summary analysis of the strengths, weaknesses, opportunities and threats in the form of a SWOT matrix.

Figure 2.

The results of the SWOT analysis are in the form of a matrix

\begin{tabular}{lll} 
Internal & Streght (S) & Weakness (W) \\
& Village autonomy and & 1. Inadequate infrastructure \\
2. & Have PADes & 2. Has large peatlands \\
3. & $\begin{array}{l}\text { Increase in the number of } \\
\text { production }\end{array}$ \\
4. & Extensive Forest \\
5. & $\begin{array}{l}\text { The availability of a } \\
\text { restaurant business }\end{array}$ \\
& & \\
\hline $\begin{array}{l}\text { Opportunity } \\
\text { (O) }\end{array}$ & Strategy S-O & Strategy W-O \\
\hline
\end{tabular}




\begin{tabular}{|c|c|c|}
\hline $\begin{array}{l}1 . \quad \text { Developm } \\
\text { ent priority } \\
\text { target villages }\end{array}$ & $\begin{array}{l}\text { 1. Utilizing human resources } \\
\text { in maintaining natural } \\
\text { resources for sustainable } \\
\text { development }\end{array}$ & $\begin{array}{l}\text { 1. Development } \\
\text { infrastructure in the } \\
\text { agricultural or plantation } \\
\text { sector. }\end{array}$ \\
\hline 2. There is & & \\
\hline $\begin{array}{l}\text { assistance from } \\
\text { the ministry of }\end{array}$ & $\begin{array}{l}\text { 2. Innovation in the form of } \\
\text { adding BUMDes units }\end{array}$ & $\begin{array}{l}\text { 2. Agricultural and plantation } \\
\text { product innovation }\end{array}$ \\
\hline $\begin{array}{l}\text { PDTT in the } \\
\text { form of a clean } \\
\text { water } \\
\text { management } \\
\text { machine }\end{array}$ & $\begin{array}{l}\text { 3. Addition of types of } \\
\text { plantation production }\end{array}$ & \\
\hline
\end{tabular}

\begin{tabular}{|c|c|c|}
\hline Threat (T) & Strategy S-T & Strategy W-T \\
\hline $\begin{array}{l}\text { 1. Forest fire } \\
\text { natural disasters } \\
\text { that come at any } \\
\text { time }\end{array}$ & $\begin{array}{l}\text { 1. Collaborating with district } \\
\text { and provincial governments } \\
\text { in development planning and } \\
\text { implementation. }\end{array}$ & $\begin{array}{l}\text { 1. Marketing for } \\
\text { economic development } \\
\text { based on online village } \\
\text { potential }\end{array}$ \\
\hline $\begin{array}{l}\text { 2. Information } \\
\text { development }\end{array}$ & $\begin{array}{l}\text { 2. Local government provides } \\
\text { specific indicators for } \\
\text { assessing village status } \\
\text { 3. Increase community } \\
\text { participation in development } \\
\text { in rural areas } \\
\text { 4. Collaboration with related } \\
\text { agencies in anticipating } \\
\text { natural disasters }\end{array}$ & $\begin{array}{l}\text { 2. Cooperation in } \\
\text { marketing the local } \\
\text { products of the Kundur } \\
\text { village }\end{array}$ \\
\hline
\end{tabular}

\section{Conclusion}

From the research conducted, in determining the village status through the Village Build Index (IDM), the village of Kundur on the assessment of the social resilience index got a value of 0.878 , an economic resilience index of 0.600 and an index of environmental resilience 0.850. Then get the village index value build 0.778 , that is, with this value classified into Maju village. The strategy used by the Kundur village to improve the status of the village sustainably is an aggressive or growth strategy, which is contained in the Streghts Opportunities strategy. 


\section{References}

Amalia, Ayu diah \& Syafawie, M. 2015, Pembangunan Kemandirian Desa Melalui Konsep Pemberdayaan: suatu kajian dalam perspektif sosiologi, Sosio informa, 1 (2), 175-188. Arifah, Mir'atun Nur, 2018, Strategi Mempercepat Pembangunan Desa Mandiri. Pemberdayaan masyarakat : media pemikiran dan dakwah pembangunan, 2 (1), 171190.

Kementerian Desa Pembangunan daerah Tertinggal dan Transmigrasi, 2015, Indeks Desa Membangun, Jakarta Selatan.

Manafi, Muh Rasman. Dkk, 2009, Aplikasi konsep daya dukung untuk pembangunan berkelanjutan di pulau kecil (studi kasus gugus pulau kaledupa, kabupaten wakatobi), Ilmu perairan dan perikanan Indonesia, 16 (1), 63-71.

Mukhlis, Imam, 2010, Eksternalitas, Pertumbuhan Ekonomi dan Pembangunan Berkelanjutan dalam Perspektif Teoritis. Ekonomi Bisnis, 14(3), 191-199.

Salim, Emil, 2010, Pembangunan Berkelanjutan Peran dan Kontribusi Emil Salim. Azis , dkk (Ed), Jakarta : Kepustakaan Populer Gramedia.

Setiadi, rukuf. Dkk., 2008, Indikator pembangunan berkelanjutan kota semarang. RIPTEK, 1(2) , 1-15.

Setyowati, Eka, 2019, Tata Kelola Pemerintahan Desa Pada Perbedaan Indeks Desa Membangun (IDM) : Studi Tiga Desa di Kabupaten Malang. Ilmu Sosial Politik, 9 (2), $170-188$.

Undang-Undang Nomor 6 Tahun 2016 